\title{
PSYCHE
}

VOL. XXXIII.

JUNE 1926

No. 3

\section{NEW OR LITTLE-KNOWN AUSTRALASIAN CICADAS OF THE GENUS MELAMPSALTA, WITH NOTES ON SONGS BY IRIS MYERS. ${ }^{1}$}

\author{
By J. G. Myers,
}

1851 Exhibition Scholar for New Zealand, 1924.

The purpose of the present paper is threefold; firstly to describe a few new species brought to light by further collecting in the river-beds and mountains of the South Island, secondly to record the songs of several forms not known to us firsthand in 1924 ( $v$. Myers and Myers), and thirdly to present taxonomic notes on a number of Australian and one New Caledonian cicada which indicate the nearest relationships and the probable origin of the cicada fauna of the Dominion. It is reserved for a later paper to trace the supposed lines of evolution of the nineteen cicadas now known in New Zealand, and to show how the descendants of one immigrant form are believed to have colonised the various ethological stations offered by the diversified New Zealand countryside.

A plea is made for the completer use of the male genitalia in cicada systematics. The ædeagus at least should be dissected out and mounted for microscopic examination. After considerabletrial I prefer not to use $\mathrm{KOH}$ at all, but to dissect directly in water, either fresh or relaxed material. The lateral pieces of the ædeagus are often so tenuous as to be distorted if not destroyed by caustic, while the whole structure is relatively so great that direct dissection and careful removal of muscles is a speedy and easy task. If necessary the pygophor may be returned to its natural position after the ædeagus and one or both copulatory hooks have been removed.

${ }^{1}$ Contribution from the Entomological Laboratory of the Bussey Institution, Harvard University. No. 265. 
After the usual dehydration the ædeagus and copulatory hooks are mounted in balsam on a slip of celluloid pierced by the pin of the insect to which they belong. We may follow Mr. F. W. Edwards' method with mosquito hypandr a and leave them entirely bare of cover-slip, or we may use a cover either of glass or of celluloid. If it becomes necessary to use the genitalic material thus mounted, in a projectoscope or in a photo-micrographic apparatus, one has prepared a stock of cards of the size and shape of a microscope slide, and with a strip of stout paper of exactly similar dimensions pasted on them by both ends. A circular hole of appropriate size is punched through both paper and card and the celluloid mount is then slipped in between paper and card so as to extend across the hole. The resulting combination can be handled in all respects like an ordinary glass microscopic slide.

A complete synonymy of these and other species will be given in my forthcoming list of the Cicadidæ of the world. It has been elucidated for the New Zealand species in a paper now in the press (Trans. New Zealand Institute, 1926). Only sufficient references are quoted here to establish the nomenclature adopted. An examination of all the types of New Zealand cicadas accomplished last summer in Europe, has led to several disturbing but necessary changes in the names of the commoner species.

\section{Melampsalta sericea (Walk.)}

Cicada sericea Walk., 1850, List Homopt. Brit. Mus., p. 169. C. nervosa Walk., op. cit., p. 213.

Melampsalta indistincta Myers, 1921, Trans. N. Z. Inst., vol. 53, p. 245 , pl. 46 , figs. 7,8 .

The above synonymy is based on a study of the types in the British Museum. The insect now labelled as type of sericea is a female, while that of nervosa is a male. Sericea is the Maorian representative of a homogeneous group of species found also in New Caledonia and in Australia, and reaching its highest development in the arid and semi-arid regions of the latter continent. The New Caledonian species, M. melanesiana is described below. The Australian representatives include the fol- 
lowing, of which the types were examined in the British Museum, while in some cases the genitalia of closely similar specimens were dissected. I owe hearty acknowledgements to the British $\mathrm{Mu}-$ seum authorities and especially to Mr. W. E. China for giving me all possible facilities.

A very useful specific character in this group lies in the development of a shining boss like a Lecaniine Coccid (e. g. Saissetia) at the base of each operculum. This swelling is markedly different in texture and often in colour from the adjacent chitin.

Melampsalta labyrinthica (Walk.): the type is a female, but a male placed as conspecific by Distant had the Saissetia swelling distinctly marked. Australia.

M. quadricincta (Walk.): the type is from King George's Sound, S. W. Australia, and all truly conspecific examples are from Western Australia. The swelling at base of operculum is very conspicuous and well-developed. A series of specimens of somewhat larger size from Yallingup, W. Australia (R. E. Turner coll.) shows a slightly wider head but agrees in male genitalic structure and in opercular characters.

$M$. sp.?: two males from W. Australia, arranged under quadricincta have the opercular swellings less distinct and are in other respects different, but cannot be described without comparison with types in Australia.

$M$. latorea (Walk.): the type has the opercular swelling very distinctly developed. Most of the examples in the British Museum are from W. Australia and the species is almost certainly synonymous with quadricincta from the same region, but the male genitalia must be dissected to establish this.

M. waterhousei Dist.: the type has the opercular swelling il -developed.

M. labyrinthica (Walk.): the type is a female but a male placed as conspecific has the opercular swelling distinctly marked. Australia.

M. mackinlayi Dist.: the type is a female but a male placed as conspecific has no signs of the opercular swelling. Queensland.

$M$. stradbrokensis Dist.: the type has indications of the opercular swelling but not very distinct. This species, from 
Stradbrooke Island, is darker than most of the other members of this group.

Of this list, quadricincta, nervosa, $M$. sp.?, with melanesiana and the New Zealand alpine cicada, cassiope Huds., were placed by Distant under the synonymy of the first-named. The name quadricincta is therefore to be expunged from New Zealand lists. Sericea, of which nervosa is a synonym, is nearest to melanesiana and to quadricincta. To the latter it is closer in facies and in width of head, but the two are distinct in opercular structure since sericea has no signs of the swelling so highly developed in quadricincta. To meianesiana it is related in opercular structure, the swelling being very feebly developed in the New Caledonian species, but the facies is different largely on account of the wider head of the latter. Sericea is fairly distinct from both in male genitalic characters.

Needless to say, the synonymisation of cassiope with nervosa or with any other species of this group has no foundation in morphology or even in appearance. But M. viridicincta Ashton (1912, p. 78, pl. 7, fig. 5) from Perth, W. Australia, certainly belongs to this group, and judging from the description is almost certainly a synonym of quadricincta.

The genitalia of several forms from the group under discussion are figured.

\section{Melampsalta melanesiana sp. $n$.}

$0^{x}$. Head very short and very wide-wider than anterior part of pronotum and equal to widest part of pronotum. Mesonotum comparatively narrow. Abdomen long oblong, somewhat laterally compressed. (This compression may be due to drying, but related species do not dry thus). Not hairy. Seventh sternite long, somewhat truncate apically. Venation normal for the genus. Fore femora with the usual three spines beneath. Aedeagus as figured (4). Hind tibia with five spines not counting the apical ones Opercula short and well-separated with practically no signs of the shining boss at the base.

Color black with greenish and testaceous markings as follows,-greenish markings.-anterior border and posterior tri- 
angular spot of vertex, hind border and longitudinal lanceolate mark on pronotum, four fasciæ and most of cruciform elevation and visible portion of metanotum; testaceous markings,--very narrow fore border of pronotum, two oblique fasciæ on each side of pronotum and posterior edge of abdominal segments, margin of frons, rostrum except tip, and most of anterior two pairs of legs. Ventral surface in general fuscous, with thoracic sterna black, and pleura, opercula and hind legs very pale greenish.

Length to tip of last tergite, $18.0 \mathrm{~mm}$.; length of head, 1.5 ; width between eyes, 2.9 ; length of pronotum, 2.6 ; length of mesonotum, 4.0; length of tegmen, 21.4; greatest width of tegmen, 7.7; ratio of length of 2nd antennal segment to that of 3rd, 1.7:1; ratio of width between eyes to length of vertex, 2.9: 1.5 , or 0.52 .

Described from 5 males, Plaine des Lacs, New Caledonia (coll. P. D. Montague), and placed by Distant in the British Museum collection under quadricincta and thus recorded (Dist., 1920, p. 459).

Holotype: Plaine des Lacs, N. C., 20th February. 1914. British Museum.

Paratopotypes: 3 ma es, February, 1914.

Paratype: 1 male, Kuakué, New Ca!edonia, 14th May, 1914.

This species is not at all likely to be confused with any of the other New Caledonian species of Melampsalta. There is but little variation in size in the series examined and still less in color. The largest is $19 \mathrm{~mm}$. long, and the smallest (from Kuakué) $15 \mathrm{~mm}$.

The holotype and all other material are in the British $\mathrm{Mu}-$ seum, save two paratopotypes in my collection.

\section{Melampsalta oromelaena sp. $n$.}

Form stout, widest at third abdominal segment. Head much narrower than pronotum. Seventh sternite very short, widely rounded apically, very slightly indented. Venation normal for the genus. Veins fuscous, black apically. Whole body very hairy with long black hairs and short white decumbent pubescence, the latter especially marked in female and 
producing in that sex a generally grey appearance. Hind tibiæ with five spines exclusive of apical ones. Opercula very short, crescentic, barely hiding the underlying cavities. Axillary membranes distinctly white. Aedeagus as in figure 8 .

Color jet-black, male immaculate save for opercula which are largely whitish, and the following testaceous markings,an almost imperceptible edging to abdominal tergites except the basal two or three, a narrow edging above antennal scrobe, sides of face, posterior margins of abdominal sternites. Female with wing-veins paler, apex of vertex, sides of pygophor and most of venter pale testaceous; also testaceous are two marks on each side of disc of pronotum, its posterior margin very narrowly, most of cruciform elevation and a narrow posterior margin to mesonotum. A silvery median longitudinal line on abdomen formed by white pubescence. Fore femora olivaceous striped with black.

Dimensions in $\mathrm{mm}$. (first figure, male, second, female).Length to tip of last tergite, 19.0; 20.1; length of head, 1.7; 2.3 ; width between eyes, $2.5 ; 3.0$; length of pronotum, 2.5; 3.0 ; length of mesonotum, $3.9 ; 4.7$; length of tegmen, 18.8; 21.0 ; greatest width of tegmen, $7.0 ; 8.1$; ratio of second antennal segment to third, in length, 1.6:1 ( $\sigma^{\gamma}$ o $)$; ratio of width between eyes to length of vertex, .70;.77.

Holotype, male, Mt. Cleughearn, Hunter Mountains, Southland, New Zealand, 3,000 feet, 25th June, 1917, A. Philpott. (Myers collection).

Allotype, female, same data as holotype. (Myers collection.)

Paratopotypes, 2 males, 3,000 feet, 22nd January, 1914, A. Philpott.

Paratypes, 2 males and 4 females Mt. Cook, 4500 feet, 11th March, 1923, R. J. Tillyard. One male of these is only $15 \mathrm{~mm}$. long, but agrees in ædeagal structure and in other respects. The females are much blacker than the type and what pale markings they possess are not testaceous but drab.

Females referred without certainty to this speces.-Two from Lake Wakatipu, 3,600-4,000 feet, February, 1911, G. V. Hudson; one from Ben Lomond, 20th December, 1913, A. Phil- 
pott; one from Arthur's Pass, 3,000—4,000 feet, February, 1920, G. V. Hudson.

In the present fragmentary state of our knowledge of the mountain cicadas of New Zealand, it is very difficult to separate the females of some of the species of which the male genitalia are remarkably distinct The most useful character so far used is the ratio of the length of the vertex to the width between eyes.

Oromelcena is a high mountain form nearest to nigra, but distnguished by its larger size and different ædeagus (fig. 8).

Melampsalta mangu F. B. White.

F. B. White, 1879, Ent. Mo. Mag., vol. 15, p. 21.

M. quadricincta (part) Myers, (nec Walk.), 1921, Trans. N. Z. Inst., vol. 53, p. 246, (pl. 45, figs. 3, 4, are not this species but true cassiope).

Buchanan White evidently had two species before him, comprised in four examples from "Porter's Pass, Canterbury, about 3,500 feet," collected by Wakefield. The bulk of the description seems to refer to the common alpine cicada named by Hudson, Cicada cassiope, but hitherto placed in the synonymy of the quite unrelated Australian M. quadricincta (Walk.) as we have noticed previously. But the only remaining material of $M$. mangu in the Buchanan White collection is a female in poor condition, labelled "mangu," presumably in White's handwriting and with the locality, "Porter's Pass," but lacking a date. It is reasonable to suppose that this is one of the original four, and therefore by elimination to be considered the type of $M$. mangu. It is not conspecific with cassiope, but with a form of which we have a series from the Dun Mountain, and which we were about to describe as new. Buchanan White's specimen differs only in the fact that the hind tibiæ have a dark ring near the middle, but the leg coloration in Melampsalta, especially the mountain forms, seems very variable.

The large and altogether black species mentioned by White at the close of his description, is probably conspecific with oromelana sp. n., just described.

The following is a re-description of the type of mangu.- 
Much worn, blackish with reddish yellow markings as follows,a longitudinally grooved spot on middle of posterior margin of vertex, one on each side on the ledge overhanging the antennæ, a faint median longitudinal line on disc of pronotum, almost whole of cruciform elevation except anterior entrant angle, a very narrow edging to abdominal tergites, almost invisible dorsally, a large smooth patch on side of eighth segment, an irregular marking along side of pygophor, most of ventral surface and legs. The legs are striped in typical fashion with black, differing from my Dun Mt. examples only in possessing a blackish ring on midde of hind tibiæ.

A few colorless long hairs, especially on head and posterior part of abdomen. A fairly dense covering of fine close golden prostrate pubescence, save on salient points like disc of mesonotum, whence it was probably rubbed off.

Fore femora both badly damaged, but apparently as in Dun Mt. specimens, with which the type agrees also in the spines of the hind tibiæ. Eyes pale. A yellowish spot at base of second antennal segment apparently not present in Dun Mt. examples. Wings very murky - possibly the insect was killed too soon after emergence. Veins all brownish, not dark. Rostrum reaching middle coxæ. Frons tumid with the striæ filled with golden pubescence, looking like stripes on the jet-black ground color.

Dimensions in $\mathrm{mm}$.- Length to tip of last tergite, 18.4; length of head, 2.3; width between eyes, 2.7 ; ratio, .84; length of pronotum, 2.5; length of mesonotum, 4.0; length of tegmen, 18.0; greatest width of tegmen, 6.7 ; ratio of lengths, 2 nd to 3 rd antennal segments, 1.4:1.

The males of the Dun Mountain examples, as usual in Melampsalta, are darker than the females, the chitin co or being almost immaculate black, but the general color is greyish owing to the covering golden pubescence. The insect rests on bare rocks in the fell field and is extremely hard to see. We have exam ned the following material.-

A series of both sexes in the collections of the Cawthron Institute and of myself, all taken on the Dun Mountain, Nelson 14th December to 23rd January at elevations from 3,000 to 4,000 feet. A single female is doubtfully referred to this species 
from Mount Tapuaenuku, 3,000 to 4,000 feet (coll. G. V. Hudson, 14th February, 1890). From the Dun Mountain material I have selected a male plesiotype (in my collection) and figured the genital a. I expressly refrain from declaring this the allotype of mangu, for material from the type locality of the latter species may prove my identification, based on the single female, to be incorrect.

The song of Melampsalta mangu.-The song of the insect which we have identified with Buchanan White's $M$. mangu is extremely low-pitched-so low as to be almost imperceptible to some ears until attention is called to it. I has a very dull, toneless quality, and sounds rather like a buzzing wing vibration. It consists of a series of slow vibrato phrases of two notes of the same pitch at a rate of approximately one note in 2 seconds. The first, longer note of the phrase sounds, when one is nearer to the insect, more like a series of discrete staccato notes. Because of the vague muffled quality of tone the nsect is almost unlocalisable by sound. Partly because it is over two octaves lower in pitch, and partly because of the tonal quality accompanying this, the song of $M$. mangu is utterly unlike that of any other New Zealand. cicada so far heard.

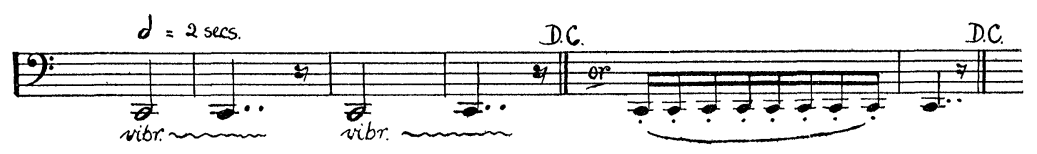

\section{Melampsalta campbelli Myers}

1923, Trans. New Zealand Inst., vol. 54, p. 430.

The male, discovered since the above was written, may be described as follows,-Head considerably narrower than pronotum. Abdomen somewhat oblong. Seventh sternite very short and wide, narrowing and sinuate apically. Venation normal for the genus. Head and thorax especially, moderately hairy with long black hairs. (The female holotype was worn and smooth). Opercula moderately large with shining black slightly elevated area at base. Aedeagus as figured (12). 
Coloration much as in female described in 1923, but on the whole much darker, especially on the abdomen, which is largely black, the tymbals pale. Seventh tergite posteriorly margined with olivaceous and eighth very widely with red and tipped with shining silver pubescence. A median longitudina dorsal line formed by patch of this pubescence on nearly every tergite and an edging to the third to eighth tergites laterally, conspicuous in dorsal view but less so from lateral aspect. Veins red, darker apically, the tegmen suffused very strongly with olive-brown. Axillary membranes of tegmen and of hind-wing and much of anal area of latter china-white.

Dimensions in $\mathrm{mm}$. (the second figure in every case is that of paratype female).-Length to tip of last tergite, $15.0 ; 15.5$; length of head, $1.5 ; 1.9$; width between eyes, $2.4,2.4$; ratio, $.63 ; .80$; length of pronotum, $2.4 ; 2.4$; length of mesonotum, $3.0 ; 3.0$ length of tegmen, $15.0 ; 14.0$; greatest width of temen, $5.5 ; 5.4$.

Allotype, male, Otira, New Zealand, 1,700 feet, 5th January, 1923, Iris Myers. (Series taken)

Other material has been examined as follows - Examples from Mt. Cook, 2,500 feet, 8th March, 1923, R. J. Tillyard; from Waiau, Southland, 19th January, 1914, A. Philpott; from White Rock, North Canterbury, December, 1918, S. and C. Lindsay.

All these specimens agree in being much darker than the types and with less suffusion in the tegmen, at least than in freshly caught examples. For these reasons the males from Waiau and from White Rock were not previously recognised as conspecific with the females on which the description of the species was based.

A freshly caught female is less brilliant than the holotype, which had evidently bleached out much of the darker color, together with the suffusion of the tegmina.

The song of Melampsalta campbelli.-This song is faint, slow and of a muted quality rather resembling that of $M$. scutellaris, of which it is occasionally reminiscent also in rhythmic structure (C) though quite distinct. The cicada was first heard (at Otira in January, 1923) singing when the sun was hidden by clouds. A long note, lasting 6 seconds, was followed by a mono- 
tonous, disjointed series of staccato notes of uniform pitch, at a rate of 1 per second. The sun suddenly came out and song (A) became more spirited, resolving itself into song (B), slightly rasping, varied in volume and rhythm, with a rise and fall in pitch of a major third, or sometimes a major fifth as in phrase (C) which was an occasional variant of the preceding phrase. This had a vocal quality which may be expressed as "oo-er-ih."

Unfortunately the song was heard unexpectedly at a time when no exact means of determining pitch was at hand. It was judged to lie somewhere in the octave between C 256 vs. and C 512 vs.

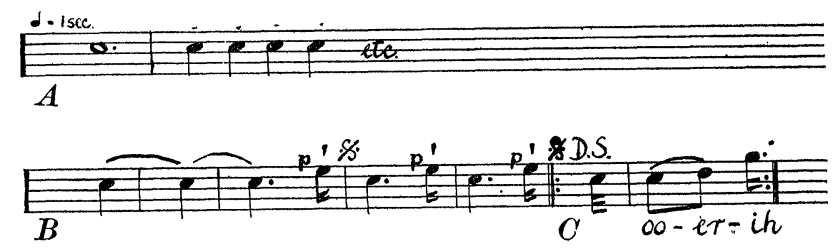

Melampsalta hamiltoni sp. $\mathrm{n}$.

Very short and squat, especially in the female. Vertex narrow, slightly produced. Antennæ unusually long. Seventh sternite of male short, truncate, almost rectangular. Venation normal for the genus; veins fuscous, black apically; in the female basally pale brown. Hind tibiæ with five spines exclusive of apical ones. Opercula extremely short, failing to cover the underlying cavity. Aedeagus as figured (11).

Color uniform dark grey in both sexes, due to paler hairs and especially to an even extremely short golden pubescence obscuring a jet-black chitin color. Even the opercula are black (in other spp. usually paler than rest of body). Fore femora uniform black. Venter black except for suggestions of paler markings on segmental margins, thoracic pleura and apices of hind tibiæ. Axillary membrane of tegmen basally yellowish.

Dimensions in $\mathrm{mm}$. (second figure that of female).-Length to tip of last tergite, $15.5 ; 15.0$; length of head, $1.9 ; 2.2$; width between eyes, $2.5 ; 2.6$; ratio, .76; .84; length of pro- 
notum, $2.3 ; 2.3$; length of mesonotum, $3.4 ; 3.6$; length of tegmen, $15.4 ; 15.4$; greatest width of tegmen, $5.2 ; 5.2$.

Holotype, male, Arthur's Pass, New Zealand, 2,500 feet, 19th December, 1922, Iris Myers. (Myers collection).

Allotype, female, same station, 24th December, J. G. Myers. (Myers coll.)

Paratopotypes, series of males and one female, H. Hamilton, Myers.

Paratypes, 2 males, White Rock, North Canterbury, 26th November, 1922, S. Lindsay.

This very interesting species, apparently confined to unstable river-beds, is dedicated to Mr. H. Hamilton, who discovered the species at Arthur's Pass before we collected it there. It is very cryptically colored on the grey river-bed shingle and is one of the most difficult of all New Zealand cicadas to locate.

The song of Melampsalta hamiltoni.-When first heard from a distance th's song sounds very like a fainter edition of the song of $M$. muta. Closer acquaintance reveals distinct differences, though a resemblance in pattern and in tonal quality still remains. The song of Hamiltoni is pitched slightly lower, the rhythm of the short rather staccato notes is more broken, though the tempo is very similar, being from two to three notes per second. A striking difference, however, is that quite often in the song $(v . \mathrm{B})$ a series of long drawn out notes is accompanied by a peculiar low buzzing sound, perhaps made by the wings, though this has not yet been ascertained.

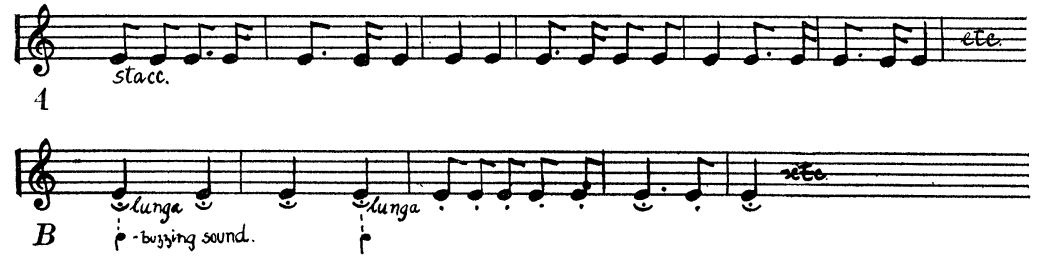

Melampsalta cassiope (Huds.)

Cicada cassiope Hudson, 1891, Trans. N. Z. Inst., vol. 23, p. 54. Melampsalta quadricincta Myers (nec Walk.), 1921, Trans. N. Z. 
Inst., vol. 53, p. 246, pl. 45, figs. 3, 4. (Exclusive of synonymy).

With the disposal of quadricincta Walk. and mangu Buchanan White, this species, the most widely distributed and best known of New Zealand mountain cicadas, fittingly takes once more the name given it by $\mathrm{Mr}$. G. V. Hudson, than whom no one has contributed more towards a knowledge of the mountain insects of the Dominion.

The description and figures of quadricincta (Myers, nec Walker) in Myers (1921), apply correctly to cassiope, but the synonymy and distributional records are to be disregarded. The male genitalia of a specimen compared with the type material are figured (14). A strong pinkish suffusion of the body is a constant character.

The mountain cicadas of the South Island are now so numerous, and often very difficult to separate by general appearance that I have thought it worth while to figure the aedeagus and related structures in them all. With no exception the male genitalia supply excellent distinguishing characters.

The song of Melampsalta cassiope.-This consists of a resonant, birdlike prolonged lower note which may be vocalised as a vibrating "chur-r-r," rising in a slur to a faint, very much higher note, like a shrill squeak. The second note sounds distinctly like "-i-i-m" the whole phrase of the song giving the effect of "chur-r-r----im" unmistakably.

The song is always slow and consists solely of a repetition of these two notes, both prolonged. The time of prolongation of each note varies so that there is no fixed rhythmical relation between them; for example in the sample given the first "churr" was observed to last 1 second, the "im" $2 \frac{1}{4}$ seconds, the second "churr" 4 seconds, the "im" 8 seconds, the third "churr" 10 and the "im". 2. The song produces a peculiar spatial effect, the insect being localised much nearer on the low note than on the high one.

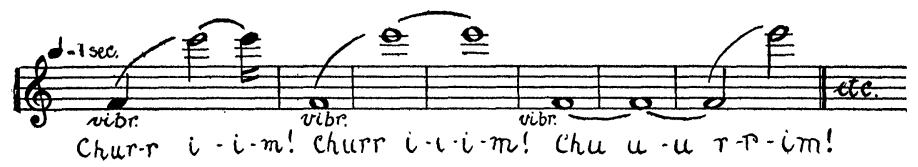




\section{Melampsalta muta (Fabr.)}

Tettigonia muta Fabricius, 1775, Syst. Ent., p. 681.

Melampsalta muta Kirby (part), Distant (part), Hudson (part), Hutton, Kirkaldy, nec Myers.

Melampsalta cruentata, authors including Myers (nec Fabricius), 1921, Trans. N. Z. Inst., vol. 53, p. 244, pl. 46, figs. 9-11.

This is perhaps the most variable cicada known. The elucidation of its manifold forms has been far from assisted by the century old misidentification of the type. Muta is a dominant species which has been and perhaps still is in an extremely plastic condition, mutating (?) right and left and occupying most of the less extreme ethological stations suitable for Cicadidæ.

It has been possib'e to collect very large series of this species from widely distant localities. This has led to the securing of complete chains of intermediates between the extreme forms and thus to a demonstration of specific identity. No attempts to split off segregates worthy of specific rank have so far been successful. Always a collecting excursion in an intermediate station, either geographically or ethologically, has brought to light connecting links. These annectent forms have shown themselves intermediate even in song, perhaps the most stable single character in cicadas.

We divide the species therefore into the following three varieties, for which names are already available.-

Var. a. muta (Fabr.) (as above).

Synonyms.-Cicada rosea, Walk., 1850, List Hom. Brit. Mus., p. 220.

C. angusta Walk., 1850, op. cit., p. 174.

C. bilinea Walk., 1858, op. cit., Suppl.; p. 34 .

C. muta Huds., and vars. flavescens, cinerascens, rufescens, 1891, Trans. N. Z. Inst., vol. 23, p. 51.

Var. b. subalpina (Huds.), 1891, Trans. N. Z. Inst., vol. 23, p. 51.

Synonyms.-Melampsalta subalpina (Huds.), Myers and Myers, 1924, Rep. Austr. Ass. Adv. Sci., (1923), p. 428. 
Var. c. cutora (Walk.), (Cicada), 1850, List. Hom. Brit. Mus., p. 172.

Synonym.-Melampsalta muta var. subalpina Myers (nec Hudson), 1921, Trans. N. Z. Inst., vol. 53, p. 257. (From Kermadec Islands).

Just as subalpina connects cutora with var. muta, so cutora shows that ochrina is almost certainly derived from muta, though the result is sufficiently distinct to merit specific rank. Superficially cutora is more like ochrina than like muta, but the series of transitional forms between the latter and cutora is complete, while intermediates in any sense between cutora and ochrina (muta Myers, 1921, nec Fabr.) have not been found.

In 1921 (p. 244) I wrote, "It is interesting to note that this [muta Fabr.] is the only species not endemic. Goding and Froggatt ('Monograph of Australian Cicadidæ') record it from Adelaide and Victoria." We know now that this cicada is entirely confined to New Zealand. No authentic foreign specimen is known. Ashton (1912, p. 25) remarks that $M$. angusta God. and Frogg. nec Walk. is a synonym of $M$. binotata God. and Frogg. Their angusta is thus the male and their binotata the female of a species quite distinct from angusta Walk. which is a synonym of the Maorian M. muta (Fabr.).

In conclusion I should like to thank all the collectors mentioned in these pages for giving me the opportunity of studying their material.

\section{Explanation of Plate III.}

(Figures 7-14 inclusive are magnified exactly half as much as figures $1-6$ ).

1. Melampsalla quadricincta (Walk.). ædeagus and copulatory hook of a specimen from Swan R., compared with type.

2. Melampsalta melanesiana sp. n., copulatory hook.

3. Melampsalta quadricincta (Walk.), ædeagus of example from S. W. Australia.

4. Melampsalta melanesiana sp. n., ædeagus.

5. Melampsalta sericea (Walk.), ædeugus and copulatory hook of form from Hawkes Bay.

6. Melampsalta sericea (Walk.), ædeagus of typical form.

7. Melampsalta mangu Buchanan White, ædeagus and copulatory hook of example from Dun Mountain.

8. Melampsalta oromeloena sp. n., ædeagus and copulatory hook. 
9. Melampsalta nigra Myers, ædeagus and copulatory hook of topotype.

10. Melampsalta lindsayi (Myers), ædeagus and copulatory hook.

11. Melampsalta hamiltoni sp. n., ædeagus and copulatory hook

12. Melampsalta campbelli Myers, ædeagus and copulatory hook.

13. Melampsalta iolanthe (Hudson), ædeagus and copulatory hook.

14. Melampsalta cassiope (Hudson), ædeagus and copulatory hook.

\section{REFERENCES.}

Ashton, H.

1912. Catalogue of the Victorian Cicadidæ in the National Museum, Melbourne. Mem. Nat. Mus., Melbourne, IV, 23-29, pl. 4, figs. b, d-h, j, k. Notes on Australian Cicadidæ. Rec. Austr. Mus., IX, 76-80, pl. 7.

Distant $_{4}$ W. L.

1920. Rhynchota from New Caledonia, Ann. Mag. Nat. Hist., (9), VI, 456-470.

Myers, Iris and Myers, J. G.

1924. The Sound-organs and songs of New Zealand Cicadidæ. Rep. Austr. Ass. Adv. Sc., (1923), XVI,420-430. 
PSYCHE 1926.

VOL. XXXIII, PLATE III.

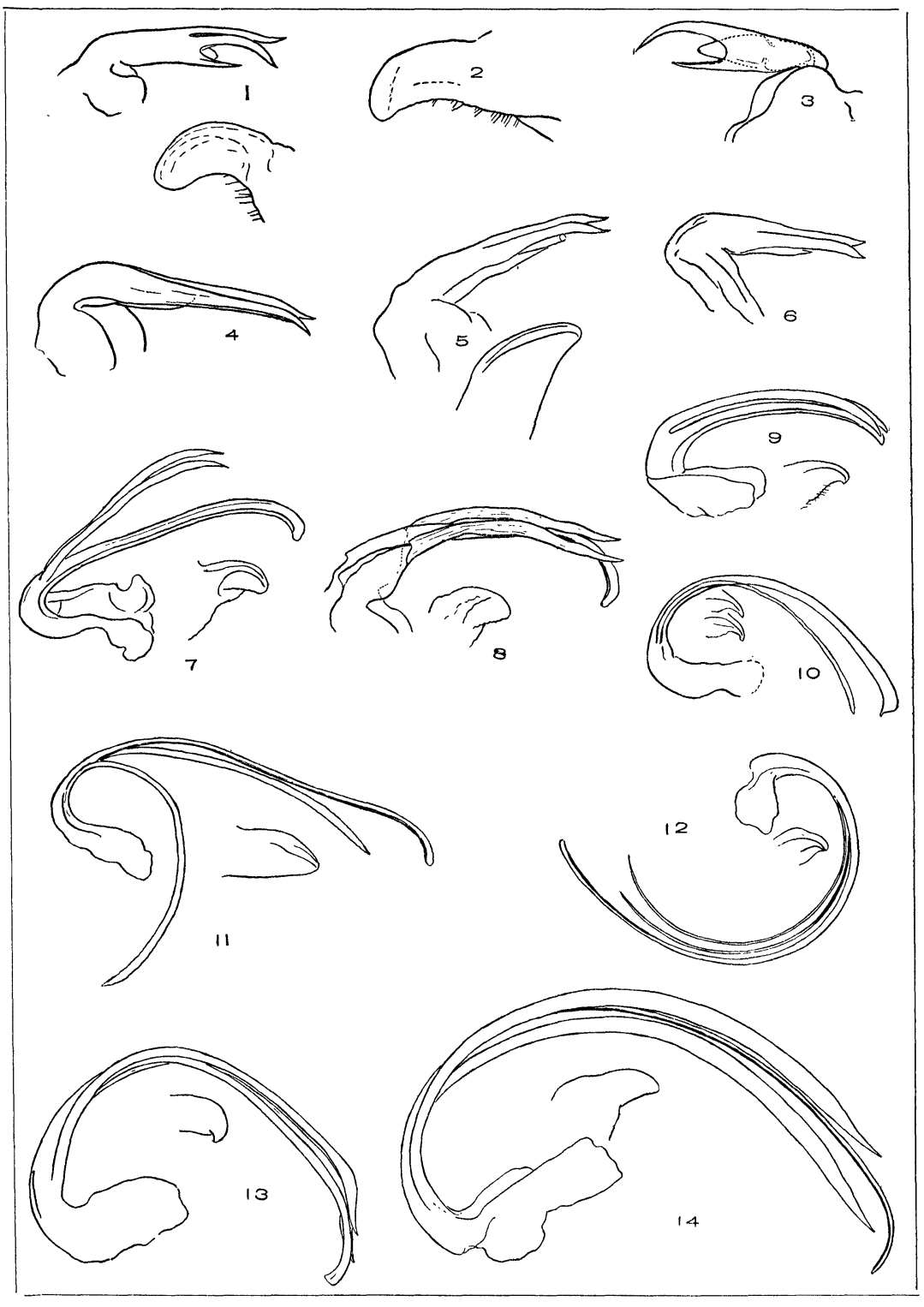

MYERS-AUSTRALASIAN CICADIDAE 

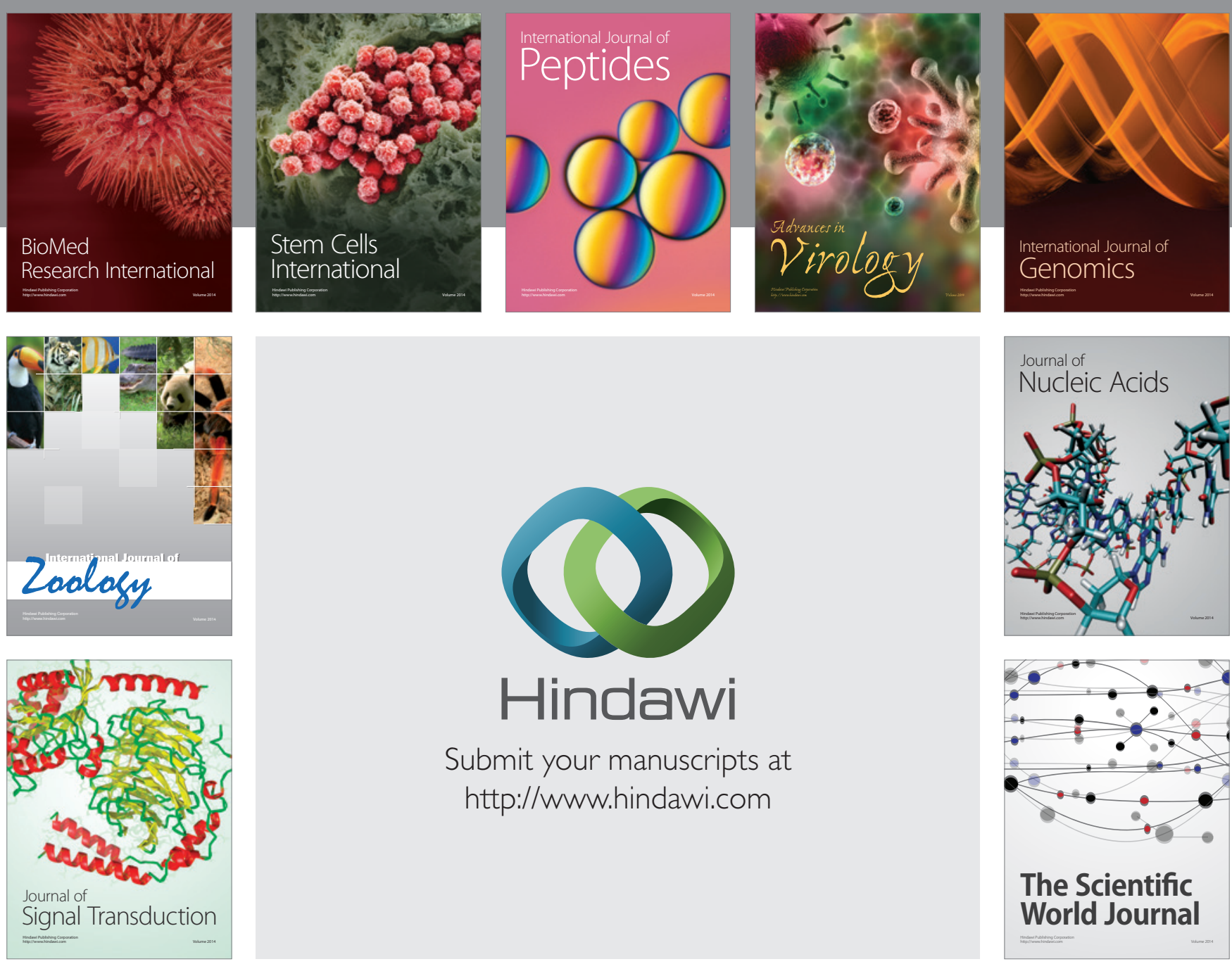

Submit your manuscripts at

http://www.hindawi.com
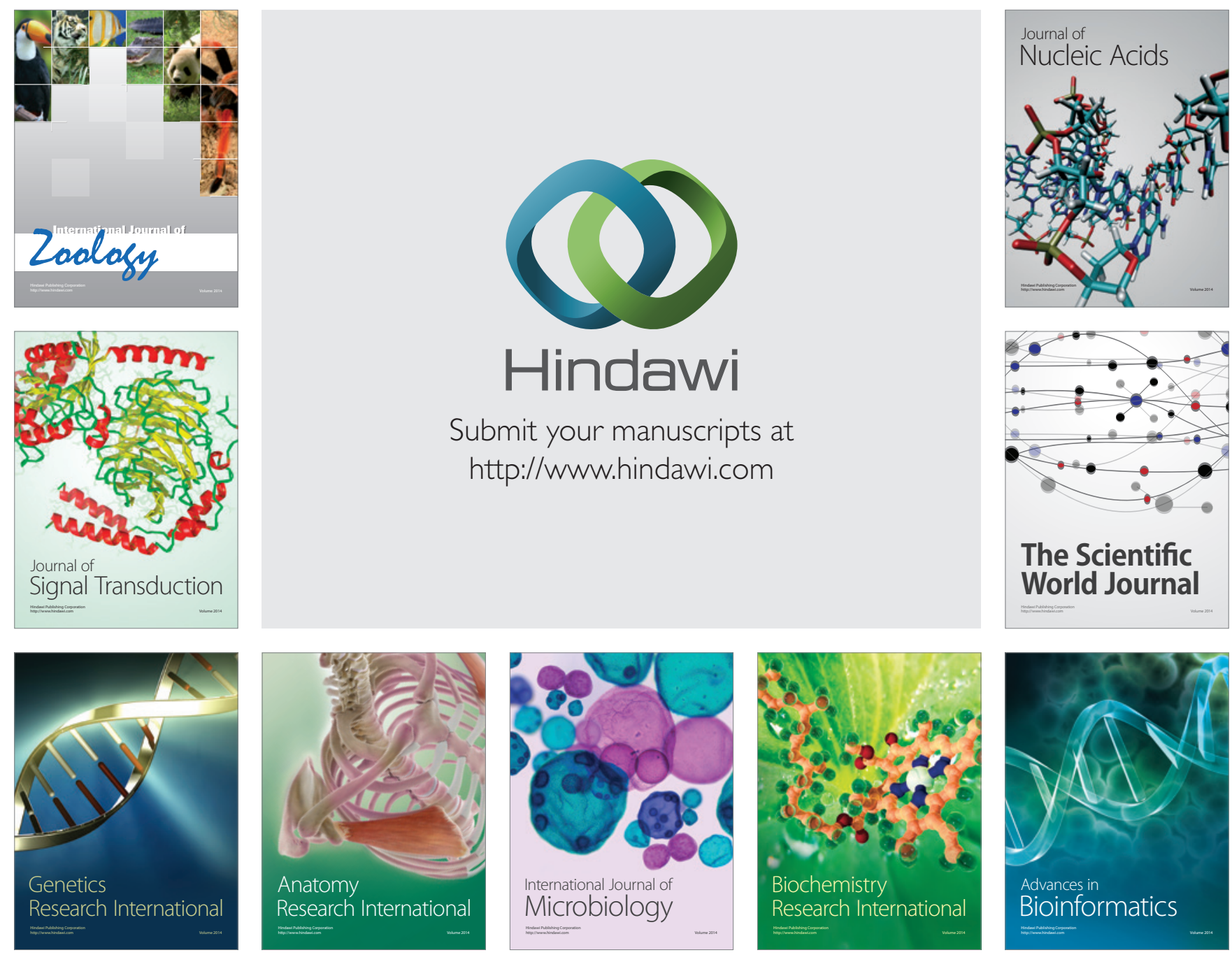

The Scientific World Journal
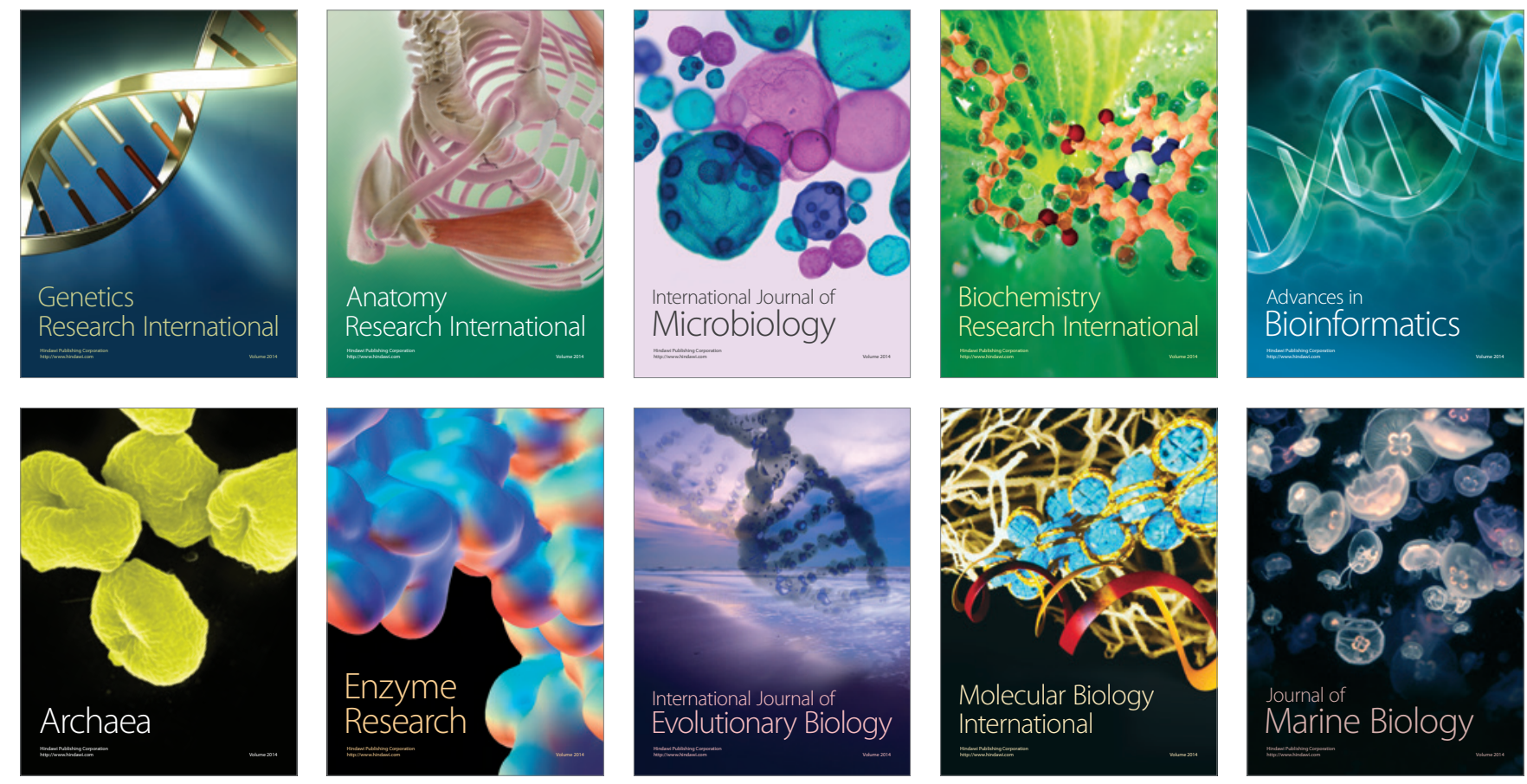